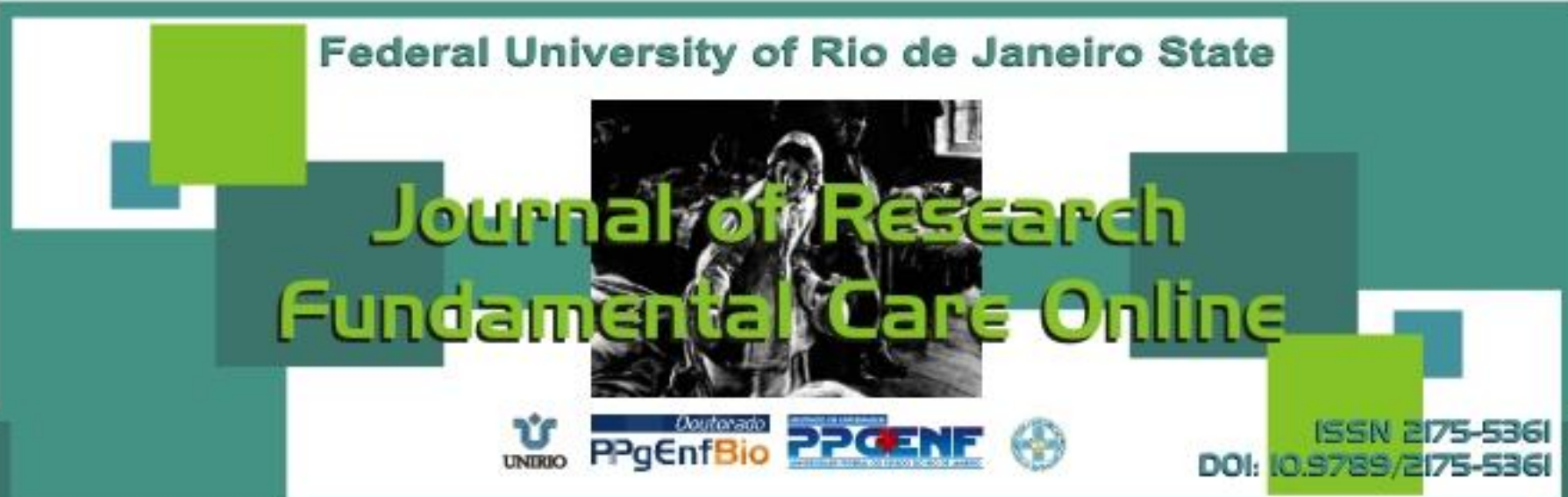

\title{
RESEARCH
}

\section{Profile of patients undergoing cardiac rehabilitation: implications for nursing}

Perfil de pacientes em reabilitação cardíaca: implicações para a enfermagem

Perfil de pacientes en rehabilitación cardíaca: implicaciones para la enfermería

Letice Dalla Lana ${ }^{1}$, Silviamar Camponogara ${ }^{2}$, Claudiane Bottoli ${ }^{3}$, Cibele Cielo ${ }^{4}$, Isabela Lencina Rodrigues $^{5}$

ABSTRACT

Objective: Outline the socioeconomic profile of users of a cardiac rehabilitation program. Method: This is a study with a quantitative approach and a descriptive design, carried out with users assisted by a cardiac rehabilitation program of a university hospital. Data were collected through a form prepared for this study, directly from the patients' medical records and, then, they underwent a quantitative analytical process. Results: One identified that most users assisted are female, married, hypertensive, diabetic, dyslipidemic, obese, and their average age is 58.5 years. It was also found out that most patients participate in the cardiac rehabilitation program for more than three years. Conclusion: One concludes that the nurse plays a key role in the cardiac rehabilitation process, in order to enable a better quality of life and minimize the possibilities of recurrence of cardiovascular events. Descriptors: Nursing, Cardiology, Rehabilitation nursing, Cardiovascular diseases.

\section{RESUMO}

Objetivo: Traçar o perfil socioeconômico dos usuários de um programa de reabilitação cardíaca. Método: Trata-se de estudo com abordagem quantitativa, do tipo descritivo, realizado com usuários atendidos por um programa de reabilitação cardíaca de um hospital universitário. Os dados foram coletados por meio de formulário próprio, diretamente dos prontuários dos pacientes e, em seguida, foram submetidos a um processo de análise quantitativa. Resultados: Identificou-se que a maioria dos usuários atendidos é do sexo feminino, casada, hipertensa, diabética, dislipidêmica, obesa e sua idade média é de 58,5 anos. Também se constatou que a maioria dos pacientes participa do programa de reabilitação cardíaca há mais de três anos. Conclusão: Conclui-se que o enfermeiro tem papel fundamental no processo de reabilitação cardíaca, com vistas a proporcionar melhor qualidade de vida e minimizar as possibilidades de reincidência de eventos cardiovasculares. Descritores: Enfermagem, Cardiologia, Enfermagem em reabilitação, Doenças cardiovasculares.

RESUMEN

Objetivo: Trazar el perfil socio-económico de los usuarios de un programa de rehabilitación cardíaca. Método: Esto es un estudio con abordaje cuantitativo, del tipo descriptivo, realizado con usuarios atendidos por un programa de rehabilitación cardíaca de un hospital universitario. Los datos fueron recogidos por medio de un formulario propio, directamente de los prontuarios de los pacientes y, entonces, fueron sometidos a un proceso de análisis cuantitativo. Resultados: Se identificó que la mayoría de los usuarios atendidos es del sexo femenino, casada, hipertensa, diabética, dislipidémica, obesa y su edad media es de 58,5 años. También se constató que la mayoría de los pacientes participa en el programa de rehabilitación cardiaca hace más de tres años. Conclusión: Se concluye que el enfermero desempeña un papel clave en el proceso de rehabilitación cardíaca, con el fin de proporcionar mejor calidad de vida y minimizar las posibilidades de recurrencia de eventos cardiovasculares. Descriptores: Enfermería, cardiología, Enfermería en rehabilitación, Enfermedades cardiovasculares.

${ }^{1}$ Specialist Md of Graduate Biomedical Gerontology of the Catholic University of Rio Grande do Sul (PUCRS-POA). E-mail: leticedl@hotmail.com. ${ }^{2}$ Prof. Dr. Department of Undergraduate Nursing, Federal University of Santa Maria (UFSM-RS). E-mail: claudianenf@yahoo.com.br. ${ }^{3}$ Specialist (HUSM-RS) University Hospital of Santa Maria. Email: silviaufsm@yahoo.com.br. ${ }^{4}$ Student at Undergraduate Nursing UFSM-RS. E-mail: cibelecielo@yahoo.com.br. ${ }^{5}$ Student at Undergraduate Nursing UFSM-RS. E-mail: bela_1806@hotmail.com. 


\section{INTRODUCTION}

urrently, chronic degenerative diseases have assumed increasingly alarming proportions in world society, especially cardiovascular diseases, which affect about 13 million people worldwide. ${ }^{1}$ In Brazil, cardiovascular diseases are the leading cause of death. ${ }^{1,2}$ However, one observes that this epidemiological information, in recent decades, had a small decline, which may be related to geographic distribution, age group, gender, ethnic group, and socioeconomic level. ${ }^{3}$

Another aspect which may be related to this decline refers to the development of cardiac rehabilitation programs, aimed at users with cardiovascular pathologies. Such programs constitute an important strategy for following up users, as well as a space for conducting educational activities. Moreover, they're regarded as a health care process which seeks better physical, mental, and social conditions, contributing so that people with a cardiovascular problem are able to regain a position in the community and lead an active and productive life in society. ${ }^{4}$

This way, rehabilitation may prevent the onset of social isolation, anxiety, depression, and personal dependency, constituting an imperative therapy to treat these users. ${ }^{5,6}$ However, rehabilitation demands the dynamic, participatory, and active collaboration between the cardiac patient, the family, and the interdisciplinary team. ${ }^{7}$ That is, there's a need to have involvement on the part of patients and their relatives in the planning and implementation of caring procedures, as well as the use of interdisciplinary techniques and actions on the part of the team, in order to improve and/or resume the cardiac patient's impaired or lost functions. ${ }^{8}$ Thus, the co-accountability of professionals and society, in this process, is essential, in order to stimulate and trigger actions promoting emancipation and autonomy for the patient and her/his family, taking into account their life context. ${ }^{9}$

The rehabilitation process constitutes, therefore, a fundamental strategy for nursing, since it enables direct contact to the user and her/his family, as well as following up her/his recovery process, the shared planning of health care actions, especially those aimed at the risk factor control and therapeutic support aid. Moreover, it's a space where one enables the commitment of users and their relatives to self-care, making them more likely to a satisfactory social reintegration and minimizing the possibility of recurrence of cardiovascular events.

In this sense, the nurse stands out as an educator, developing actions aimed not only at rehabilitation, but also with a preventive and health promoting nature. The nurse evaluates the user's health status and helps determining goals in the short, medium, and long terms with regard to the rehabilitation process, since it's a lengthy follow-up involving psychological, social, spiritual, economic, and political components, being, often, a challenge both for the patient and for the nurse. ${ }^{8}$ 
Obviously, planning these actions requires knowing not only the users' life context, but also the characteristics which provide the whole set of patients assisted by a certain cardiac rehabilitation program with a shape. This allows a better structuring of educational and rehabilitation activities, as well as the planning of joint action strategies along with the other health care professionals. Identifying the profile of users assisted by the cardiac rehabilitation programs enables nurses and the other professionals involved to plan and implement specific educational actions, with better chances to obtain a satisfactory result in the rehabilitation process itself and in the promotion of the subject's autonomy in face of her/his illness, besides making possible to adopt strategies aimed at quality of life and wellbeing.

Given the above, this study was guided by the following research question: "What is the profile of users assisted by a cardiac rehabilitation program of a university hospital?". The expectation is obtaining data which provide support for the planning of actions in the program which constituted the locus of this study, as well as stimulating debate on the importance of the nurse's work in these programs.

\section{METHODOLOGY}

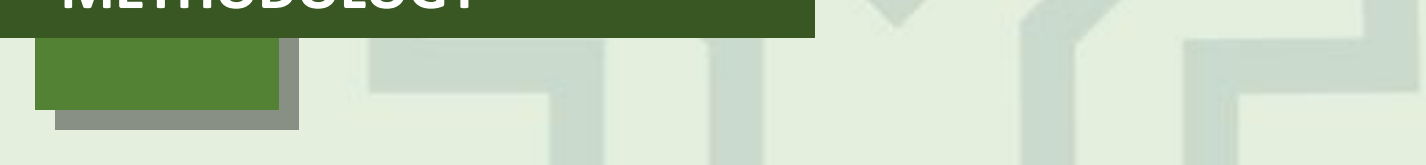

This is a quantitative research, with a descriptive design. The study setting was an outpatient cardiac rehabilitation ward, where a Secondary Cardiac Rehabilitation Program operates, located at a university hospital in a town in the countryside of the state of Rio Grande do Sul. The program indicated was created in 2007, and it consists of 1 cardiologist, 1 physiotherapist, 1 nutritionist, 1 physical educator, 1 psychologist, and 1 nurse. It's noteworthy that the latter professional works in another service of the institution and he's authorized only once a week, for 2 hours, to work in the Cardiac Rehabilitation Program.

The program operates in accordance with the Brazilian Cardiac Rehabilitation Guideline, which covers the rehabilitation phases. ${ }^{10}$ At phase I, the actions of this program are conducted by physical therapy and medicine at the bedside. Phases II and III take place at the program's facilities, with all professionals, except the physical educator. In turn, phase IV is particularly practiced by the physician and the physical educator, in a space outside the hospital environment.

The activities conducted in the program cover center actions, which vary according to the health care needs of each user, and field actions conducted through biweekly meetings with the multidisciplinary program's team. Thus, each professional center develops its practices in an individualized manner, seeking an integral, contextualized, and humanized care. In turn, the field activity is conducted through biweekly meetings, one of them is technical and the other administrative. The technical meeting aims to outline interdisciplinary interventions applicable to each user of the program, proposing individualized intervention strategies. And the administrative meeting aims to discuss the planning and progress of the activities undertaken by the program. 
The study population consisted of all patients assisted by the program, participating in its phases II, III, and IV, totaling 30 subjects. The inclusion criteria were: participating in the program, having a diagnosed cardiovascular disease, living in the institution's town, actively participating in the program in accordance with the activities' times and dates.

Data were collected in August and October 2011. The list of participating users was obtained through records from the program's office, identifying the patient's name and the medical record's number. Afterwards, one analyzed the medical records at the institution's file. Data were recorded in a form prepared to meet the purposes of this investigation.

For data analysis, one used the distribution of absolute and relative frequencies and analysis through the simple tabulation of variables. A database was constructed, in spreadsheets of the software Microsoft Excel 2007, and the information was analyzed and presented using simple statistics.

The project was approved by the Research Ethics Committee of the institution, under the Protocol 0183.0.243.000-11. The study followed all recommendations of the Resolution 196/96, from the National Health Council. ${ }^{11}$

\section{RESULTS AND DISCUSSION}

The results obtained by means of data collection led to the outline of a profile of participants in the Cardiac Rehabilitation Program of the institution under investigation. Table 1 shows some data related to the social profile.

Table 1 - Social data of users assisted by the Cardiac Rehabilitation Program (phases II, III, and IV), Rio Grande do Sul, Brazil, 2011.

\begin{tabular}{|c|c|c|c|c|}
\hline Sociodemographic variables & Frequency (n) & Percentage (\%) & $\mathrm{p}$ & Average \\
\hline \multicolumn{5}{|l|}{ Sex } \\
\hline Female & 22 & 73.3 & & \\
\hline Male & 8 & 26.7 & & \\
\hline \multicolumn{5}{|l|}{ Marital status } \\
\hline Married & 27 & 90.0 & & \\
\hline Single & 3 & 10.0 & & \\
\hline \multicolumn{5}{|l|}{ Education level } \\
\hline Primary Education & 12 & 40 & & \\
\hline High School & 13 & 43.3 & & \\
\hline Higher Education & 5 & 16.7 & & \\
\hline \multicolumn{5}{|l|}{ Profession } \\
\hline Active & 13 & 43.3 & & \\
\hline Inactive & 17 & 56.7 & & \\
\hline \multicolumn{5}{|l|}{ Age } \\
\hline $30-40$ & 1 & 3.3 & & \\
\hline $41-59$ & 14 & 46.7 & 9.1 & 58.5 \\
\hline $60-77$ & 15 & 50 & & \\
\hline
\end{tabular}

Data reveal that most users of the program $(22,73.3 \%)$ are female. The largest portion of the study subjects is married (27, 90\%). Other 3 subjects (10\%) are single. The average age was 58.5 years, and only 1 subject was aged between 30 and 40 years. 
Regarding the education level, the largest portion of subjects under investigation $(13,43.3 \%)$ graduated from High School. Other 12 subjects (40\%) have primary education, and $5(16.7 \%)$ graduated from Higher Education. Regarding the professional activity, most users $(17,56.7 \%)$ is inactive. Other 13 subjects $(43.3 \%)$ are active.

Table 2 - Data related to the use of licit and illicit drugs by users assisted by the Cardiac Rehabilitation Program (phases II, III, and IV), Rio Grande do Sul, Brazil, 2011.

\begin{tabular}{ccc}
\hline Sociodemographic variables & Frequency (n) & Percentage (\%) \\
\hline Used drugs & 29 & \\
No & 1 & 96.7 \\
Yes & 14 & 3.3 \\
Consumed tobacco & 16 & 46.7 \\
No & & 53.3 \\
Yes & 29 & 96.7 \\
Consumed alcohol & 1 & 3.3 \\
No & & \\
Yes & & \\
\hline
\end{tabular}

According to data presented in Table 2, 29 subjects $(96.7 \%)$ didn't use illicit drugs and didn't consume alcoholic beverages on a daily basis, while 16 users $(53.3 \%)$ consumed tobacco.

Regarding procedures underwent by the study subjects, $8(26.7 \%)$ had valve replacement, 10 (33.3\%) had cardiac catheterization, 6 (20\%) had coronary artery bypass grafting, and other 6 (20\%) had percutaneous aortic valvuloplasty.

Table 3 - Data related to the presence of associated diseases among users assisted by the Cardiac Rehabilitation Program (phases II, III, and IV), Rio Grande do Sul, Brazil, 2011.

\begin{tabular}{lcc}
\hline Associated diseases & Frequency (n) & Percentage (\%) \\
\hline Systemic arterial hypertension (SAH) & 26 & $86.7 \%$ \\
Dyslipidemia & 20 & $66.7 \%$ \\
Obesity & 22 & $73.3 \%$ \\
Diabetes mellitus (DM) & 17 & $56.7 \%$ \\
\hline
\end{tabular}

This study identified that most subjects have more than one associated comorbidity. Table 3 shows that $86.7 \%$ of individuals have SAH, $66.7 \%$ have dyslipidemia, $73.3 \%$ have obesity, and $56.7 \%$ have DM.

Regarding the use of medicines, the results point out that most subjects use some kind of drug. Among the most used drugs one finds: antihypertensive agents (90\%), antidiabetic agents $(80 \%)$, anticoagulant agents $(80 \%)$, statins $(80 \%)$, and other medicines (63.3\%).

Table 4 - Length of participation in the Cardiac Rehabilitation Program, Rio Grande do Sul, Brazil, 2011.

\begin{tabular}{|c|c|c|c|c|c|c|c|}
\hline \multirow[b]{2}{*}{ hase } & \multicolumn{2}{|r|}{6 months to 1} & \multirow[t]{2}{*}{13 months to 2} & \multicolumn{3}{|c|}{ Over 3} & \multirow[t]{2}{*}{ Tot } \\
\hline & year & years & & years & & al & \\
\hline & & 0 & $2(30 \%)$ & & 1 & & 3 \\
\hline I & & & & $(3.3 \%)$ & & $(10 \%)$ & \\
\hline & & $1(3.3 \%)$ & $4(13.3 \%)$ & & 11 & & 16 \\
\hline II & & & & $(36.6 \%)$ & & (53.3\%) & \\
\hline & & $5(16.6 \%)$ & $1(3.3 \%)$ & & $5(16.6$ & & 11 \\
\hline V & & & & $\%)$ & & $(36.6 \%)$ & \\
\hline & & $6(20 \%)$ & $7(23.3 \%)$ & & 17 & & 30 \\
\hline otal & & & & $(56.7 \%)$ & & $(100 \%)$ & \\
\hline
\end{tabular}


Regarding the length of the patients' participation in the Cardiac Rehabilitation Program, according to the rehabilitation phase concerned, one identified that 6 subjects (20\%) are undergoing rehabilitation between 6 months and 1 year, 7 subjects (23.3\%) between 13 months and 2 years, and 17 (56.7\%) over 3 years; 3 patients (10\%) are at phase II, $16(53.3 \%)$ are at phase III, and $11(36.7 \%)$ are at phase IV of the cardiac rehabilitation.

Table 5 - Professionals involved in the care for users of the Cardiac Rehabilitation Program (phases II and III), Rio Grande do Sul, Brazil, 2011.

\begin{tabular}{|c|c|c|c|c|c|c|}
\hline \multicolumn{3}{|l|}{ Professionals } & \multicolumn{3}{|c|}{ Phase } & \\
\hline & \multicolumn{2}{|c|}{ II } & \multicolumn{2}{|c|}{ III } & \multicolumn{2}{|c|}{ IV } \\
\hline & $\mathbf{N}$ & $\%$ & $\mathbf{N}$ & $\%$ & $\mathbf{N}$ & $\%$ \\
\hline \multicolumn{7}{|l|}{ Nurse } \\
\hline No & 1 & 33.3 & 6 & 37.5 & 6 & 54.5 \\
\hline Yes & 2 & 66.7 & 10 & 62.5 & 5 & 45.4 \\
\hline \multicolumn{7}{|l|}{ Psychologist } \\
\hline No & 0 & 0 & 3 & 18.5 & 5 & 36.3 \\
\hline Yes & 3 & 100 & 13 & 81.2 & 6 & 54.5 \\
\hline \multicolumn{7}{|l|}{ Physician } \\
\hline Yes & 3 & 100 & 16 & 100 & 11 & 100 \\
\hline \multicolumn{7}{|l|}{ Physiotherapist } \\
\hline No & 2 & 66.7 & 4 & 25 & 4 & 36.3 \\
\hline Yes & 1 & 33.3 & 12 & 75 & 7 & 63.6 \\
\hline \multicolumn{7}{|l|}{ Nutritionist } \\
\hline No & 2 & 66.7 & 8 & 50 & 6 & 54.5 \\
\hline Yes & 1 & 33.3 & 8 & 50 & 5 & 45.4 \\
\hline \multicolumn{7}{|l|}{ Social worker } \\
\hline No & 3 & 100 & 15 & 93.7 & 11 & 100 \\
\hline Yes & 0 & 0 & 1 & 6.2 & 0 & 0 \\
\hline Pharmacist & & & & & & \\
\hline $\begin{array}{c}\text { No } \\
\text { Physical educator }\end{array}$ & 3 & 100 & 16 & 100 & 11 & 100 \\
\hline No & 3 & 100 & 15 & 93.7 & 10 & 90.9 \\
\hline Yes & 0 & 0 & 1 & 6.2 & 1 & 9.1 \\
\hline
\end{tabular}

* No: there was no record of care for the patient since her/his inclusion in the Cardiac Rehabilitation Program. Yes: there was record of care for the patient included in the Cardiac Rehabilitation Program.

The data reveal that all (100\%) users of the program received medical care at any rehabilitation phase, according to the medical records analyzed. However, no record of treatment by the pharmacist was identified at any rehabilitation phase. In turn, the other professional records haven't been identified in all medical records analyzed. The nurse, who participates in all phases of the program, for instance, presents records of care for about $60 \%$ of users at phases II and III and $45 \%$ of users at phase IV.

Regarding the sex of study participants, the significant number of women in the Cardiac Rehabilitation Program contrasts with other studies which identified the male predominance among patients suffering from cardiovascular diseases. ${ }^{12,13}$ This percentage of women undergoing rehabilitation may be associated to the degree of recognition and concern of women about their health, especially because they identify that the rehabilitation process requires time and dedication.

Such evidence was identified in a study carried out with patients undergoing cardiac rehabilitation, where there was a predominance of women in the preventive group for heart diseases when compared to the therapeutic group, since women recognize the relevance of adopting changes in lifestyle to prevent health problems. ${ }^{12}$ In addition, the Brazilian Institute of Geography and Statistics ${ }^{14}$ points out that the number of women is higher than 
that of men, in the town where this research was conducted, something which may corroborate this finding.

The average age wasn't above 60 years, as evidenced in other studies, which detected a prevalence of elderly people in rehabilitation programs. ${ }^{12-15}$ However, one observes that the vast majority of them are above 41 years, since only one female subject was below 41 years.

According to a study carried out with people who used the Unified Health System (SUS), half of these subjects have an education level up to 3 years, that is, they have an incomplete Primary Education. ${ }^{16}$ Another study found an average of 4 years, showing that the profile of patients assisted in this system involve low education, corroborating the findings of this study. ${ }^{17}$

Regarding the profession, one identified a higher percentage of inactive subjects, matching the data revealed in the variable age, over 60 years, when people are starting to retire. However, this study was limited to information on receiving the benefit, since the data in the medical record of each subject didn't describe this observation, something which shows a gap left by the professionals who provided care for these subjects, to the extent that health also covers the economic and social well-being. This way, this aspect also needs to be addressed in the patients' anamneses, either by nursing or by other professionals.

Since heart disease is a major public health problem ${ }^{1}$ and hypertension is responsible for the high social cost, due to early retirement or work absenteeism, the professionals, including nursing, should address this aspect along with users. ${ }^{18}$ This allows one to raise problems, provide guidance and referral to the other team's professionals or specialized services, such as occupational health, preventive health programs, and social rehabilitation programs, aimed at improving these subjects' health.

Concerning the health history, one identified that the use of illicit drugs and the consumption of alcoholic beverages wasn't significant. However, half of the patients consumed tobacco. Smoking has been the leading cause of preventable death around the world due to the fact it constitutes itself as a precursor of various diseases, besides its prevalence. ${ }^{19}$ It's known that the passive smoker also has a potential risk for chronic diseases, such as the chronic lung disease which potentiates the heart diseases. ${ }^{20}$

This way, the professionals should perform health education practices which mobilize users for participation in programs for fighting smoking, ${ }^{21}$ thus minimizing the risk factors for chronic heart diseases. The nursing professionals may act proposing measures for controlling tobacco use among cardiac patients, explaining and demonstrating that abstinence leads to control of hypertension and/or heart diseases. ${ }^{22}$ Among the strategies to be adopt, one may mention: training sessions through workshops, use of educational materials, conducting roundtables, group debates on similar problems or concerns, explanation to the patients and their relatives with regard to the harms of smoking to people with a cardiac disease, as well as the design and implementation of therapeutic plans for modifying lifestyle and behavior.

In the action context where patients undergo the rehabilitation process, with an already installed heart disease, there's a need for prioritizing the education process, addressing the physiopathology of their disease; the relation of the disease to physical 
activity, sexual activity, and labor; the action mechanisms of drugs; the reformulation of feeding habits; smoking cessation and stress control, in order to resume their daily life activities on an active and productive basis. ${ }^{4}$ This way, the nurse's role, as a professional in the rehabilitation team, must aim at the functional independence of patients through selfcare, the subject's emancipation in society, the training of patients to perform daily life activities, striving for health promotion and education.

All medical diagnoses surveyed, as well as the medical procedures performed, presented benefits to patients' health, as evidenced by the Brazilian Cardiac Rehabilitation Guideline. ${ }^{10}$ Moreover, these data reveal the diversity of procedures performed at the institution, making a must to carry out training courses for nursing professionals, more specifically in the rehabilitation specialty. Thus, the nurse who is specialist in rehabilitation needs to reinforce the nursing role in rehabilitation programs, since there still exist some uncertainties and doubts with regard to its contribution to this process. ${ }^{23}$

It's known that, regardless of the heart condition, patients undergoing rehabilitation present better physiological, hemodynamic, functional, and autonomic parameters, predominantly in the patients with a coronary disease and, consequently, with regard to their cardiovascular and metabolic performance during exercise. ${ }^{13}$ This constitutes an important reason to carry out the rehabilitation at phases I, II, and II within the hospital environment, as early as possible, aiming to resume the subjects' functional capacity. ${ }^{24}$ Regardless of the distinctive profile found in other studies, it's a task of the nurse to promote the patient's self-care, respect, and well-being. Thus, the nurse can provide the patient's interests and decisions with support, cooperating in the physical, social, political, and economic environment of the subject for her/his reintegration into society. ${ }^{23}$

As an associated disease, SAH was among the most prevalent comorbidities in the study. It's known that the aging process can trigger specific physiological changes, which make individuals more likely to develop $\mathrm{SAH}$, becoming the leading chronic disease among the elderly population. ${ }^{9}$ A research which identified the prevalence of risk factors for cardiovascular disease among borderline men with regard to blood pressure values, found out that they are aged over 30 years, are black or mulatto, married, and they have an employment relationship. ${ }^{25}$ By comparing to this study, one notices an inverse ratio in the variables age, sex, and employment relationship, since this study identified a significant number of adults over 50 years, hypertensive, inactive, and married. This distinctive profile may be related to the fact that users of the cardiac rehabilitation program already exhibit some heart disease installed.

Often, heart diseases are associated to other pathologies, such as diabetes mellitus, hypertension, dyslipidemia, and lung diseases, which directly influence the individual's physiological tolerances and capacities, ${ }^{2}$ as well as overweight, regular physical inactivity, and smoking. ${ }^{25}$ This way, users with cardiovascular disorders, in most cases, present one or more associated diseases, and they require a drug treatment with more than one medicine, as evidenced in this study.

This fact requires, from nursing, along with a pharmacist, the management of care in face of the medicines used by the patient. That is, contributing to the promotion of a rational use of medicines, safely, by educating users, especially with regard to the selfmedication practice, counseling on the risks of disruption, exchange, replacement, or 
inclusion of medicines without informing the health professionals. Judicious scheduling of times for prescription/recipe and monitoring of adverse drug reactions are also important aspects to be discussed with users.

Studies point out that obesity, associated to dyslipidemia, constitutes one of the main risks for cardiovascular diseases, something which can be potentiated when there's glucose intolerance and insulin resistance. ${ }^{4-26}$ This shows that patients with cardiovascular disorder undergoing rehabilitation have, in most cases, changeable risk factors and they require efficient and effective health care interventions. This, inevitably, points to the need for creating health prevention and promotion strategies at a multiprofessional and interdisciplinary level with these users. ${ }^{19}$

The use of antihypertensive agents confirms that the vast majority of patients use medicines for the treatment and control of $\mathrm{SAH}$, since $90 \%$ use medication and $86.7 \%$ present a medical diagnosis. Regarding the use of hypoglycemic agents, one identifies that there's a greater number of users of medicines when compared to the number of medical diagnoses of diabetes, as $80 \%$ adopt a hypoglycemic agent and $56.7 \%$ have a diabetes diagnosis. This contradictory finding demonstrates that there's a gap in the filling of users' medical records. At the same time, this is a limitation of this study, since data collection took place through secondary data, often incomplete.

Concerning the other medications revealed, one identifies that these subjects suffering from heart disease have comorbidities, taking into account the range of associated diseases. This fact justifies the importance of a different look of each professional of the multidisciplinary cardiac rehabilitation team, aiming to go beyond the borders of heart disease, especially by understanding that each associated pathology demands a kind of health care. ${ }^{25}$

However, the registers by professionals in the medical records showed that not all users are assisted by the team, except of the physician providing all patients with care. This assistance primarily provided by the physician may derive from the continued use of medicines, since all patients use and depend on more than one drug for their treatment. Also, it may be associated to the traditional health care model, still focused on the assistance by the physician. On the other hand, this model contrasts with that of interdisciplinarity and patient-driven medicine, which seeks to understand the patient's needs and wishes, without restricting itself to the disease. ${ }^{26}$ This characterizes a new way of addressing the health care process, in order to cover the multiple aspects implied in the health-illness process, through the look of the various professionals in the health care team.

The nurse in a multidisciplinary team must be aware of actions taken by the other professionals, in order to connect the actions performed by the entire team, aiming to coordinate the care strategies. This fact becomes even more relevant as the nurse is regarded as a professional who has the responsibility to coordinate and link a rehabilitation program, due to her/his ability to manage the direct and indirect care for patients and their relatives. $^{23}$

It's understood that, in the first month after the surgical procedure or the health problem onset, the user presents more doubts about her/his disease, as well as questions about her/his care in face of the daily life activities. This first stage is characterized as Phase I according to the Rehabilitation Guideline, which consists in the care for users within 
the hospitalization period, requiring professional attention from a physician, physiotherapist, nurse, nutritionist, and psychologist. ${ }^{4,24}$ The program, at this phase, aims that the patient is discharged from hospital with the best possible physical and psychological status, having information with regard to the healthy lifestyle, especially concerning the cardiac rehabilitation process. ${ }^{24}$

In turn, Phase II aims to contribute to the earliest return of the patient to her/his social and labor activities, with the best possible physical and emotional status, and it's recommended that the professional team has a doctor, physiotherapist, or physical educator, a nursing team and, if there's availability, a nutritionist and a psychologist. ${ }^{4}$ According to data from the study, the only professionals who assisted the users who entered Phase II were the psychologist and physician. The nurse didn't provide assistance to all patients who entered this phase, showing that there're gaps in the work of this professional in the rehabilitation program under investigation. However, it's worth highlighting that this nurse is authorized to leave another service once a week for 2 hours, a time regarded as insufficient for an effective action along with these users.

Nurses are regarded as essential at any rehabilitation phase, since they play an integral role in the care for people, providing the rest of the rehabilitation team with an expanded knowledge of the patient's health. ${ }^{23}$ Thus, the nurse may be the organizer of discussions within the team and the manager of care provided for the user.

However, one observed that not all professionals identified as advisable assisted all patients who entered the various phases of the program. Particularly, the lack of a nurse who works exclusively at the rehabilitation program may result in discontinuity of care directly and indirectly provided to the patient and her/his family, causing problems to the management of the cardiac rehabilitation process.

This gap shows up even more present when one analyzes the length of cardiac patients' participation in the rehabilitation program, because more than half of the subjects $(56.7 \%)$ participate in the program over 3 years, and more than half $(53.3 \%)$ remains at the Phase II of the program. According to a study, the length of Phase II ranges from 3 to 6 months and that of Phase III from 6 to 24 months, ${ }^{4}$ in contrast with the data observed in this study.

The multi/interdisciplinary work constitutes a major breakthrough in the rehabilitation process of users with cardiovascular damage, insofar as it makes available the therapeutic and education support these subjects need to resume an active and productive status in the social environment. Obviously, the health care institutions need to incorporate the cardiac rehabilitation programs as a goal to be achieved, enabling human resources and infrastructure means which favor the development of these actions, constituting an important strategy for promoting and rehabilitating the users' health.

\section{CONCLUSION}


This study allowed one to outline the profile of users participating in a cardiac rehabilitation program, stimulating reflections on the participation of nursing in this process. Data revealed that users are mostly female, married, and they have a low education level. Many of them have dyslipidemia, SAH, and diabetes, requiring the use of various medicines.

It was also found that there's a participation of various professionals in the program, but not along with all users. The nurse, particularly, doesn't provide assistance to all users participating in the program under investigation. However, this kind of rehabilitation programs requires the work of various professionals, especially the effective participation of the nurse. This professional may be regarded as crucial, since she/he promotes care management, acting as an articulator in the rehabilitation process along with the other professionals, besides developing health education actions, favoring health promotion and users' well-being.

The nurse also plays a key role in the performance of actions which optimize the rehabilitation process of people with cardiovascular disease, in order to enable a better quality of life and minimize the possibilities of recurrence of cardiovascular events.

The main limitation of this study is related to the data source, since many medical records didn't contain all information. Furthermore, one suggests further studies on this theme, taking into account its social relevance and the health care process of patients with cardiovascular disease.

\section{REFERENCES}

1. Organização Mundial da Saúde. Cuidados inovadores para condições crônicas: componentes estruturais de ação. Relatório mundial. Brasília (DF): OMS; 2010.

2. Guedes D, Guedes J, Barbosa D, Oliveira J, Stanganelli L. Fatores de risco cardiovasculares em adolescentes: indicadores biológicos e comportamentais. Arq Bras Cardiol [internet]. 2006 Jun [acesso em 2012 Ago 18];86(6):439-50. Disponível em: http://www.scielo.br/pdf/abc/v86n6/29877.pdf.

3. Ruff CT, Braunwald E. The evolving epidemiology of acute coronary syndromes. Nat Rev Cardiol. 2011 Mar;8(3):140-7.

4. Carvalho T, Cortez AA, Ferraz A, Nóbrega ACL, Brunetto AF, Herdy AH, et al. Diretriz. Reabilitação cardiopulmonar e metabólica: aspectos práticos e responsabilidades. Arq Bras Cardiol [internet]. 2006 Nov-Dez [acesso em 2012 Jun 15];83(Supl 5):448-52. Disponível em: http://www.scielo.br/pdf/rbme/v11n6/a02v11n6.pdf.

5. Faro ACM. Enfermagem em reabilitação: ampliando os horizontes, legitimando o saber. Rev Esc Enferm USP [internet]. 2006 Mar [acesso em 2012 Ago 15];40(1):128-33. Disponível em: http://www.scielo.br/pdf/reeusp/v40n1/a18v40n1.pdf. 
6. Sales JV, Moraes HCR, Araújo FCS. Respostas cardiovasculares a partir da imersão na fase de recuperação do protocolo de reabilitação cardíaca. Rev Bras Promoç Saúde. 2011 AbrJun;24(2):123-8.

7. Velloso M, Jardim JR. Funcionalidade do paciente com doença pulmonar obstrutiva crônica e técnicas de conservação de energia. J Bras Pneumol [internet]. 2006 [acesso em 2012 Ago 12];32(6):580-6. Disponível em: http://www.scielo.br/pdf/jbpneu/v32n6/a17v32n6.pdf.

8. Figueiredo NMA, Machado W. O que é reabilitação. In: Figueiredo NMA, Machado WCA, Tonini T. Cuidando de clientes com necessidades especiais, motora e social. São Paulo: Difusão Enfermagem; 2004. p. 1-2.

9. Souza LM, Wegner W, Gorini MIPC. Health education: a strategy of care for the lay caregiver. Rev Latino-Am Enferm [internet]. 2007 Abr [acesso em 2012 Ago 20];15(2):33743. Disponível em: http://www.scielo.br/pdf/rlae/v15n2/v15n2a22.pdf.

10. Moraes RS. Diretriz de reabilitação cardíaca. Arq Bras Cardiol [internet]. 2005 Maio [acesso em 2012 Jun 10];84(5):431-40. Disponível em: http://www.scielo.br/pdf/abc/v84n5/a15v84n5.pdf.

11. Conselho Nacional de Saúde. Resolução n. 196/96. Diretrizes e normas regulamentadoras de pesquisa envolvendo seres humanos. Diário Oficial da União, Brasília (1996 Out 21); Sec.1.

12. Rossi RC, Vanderlei FM, Medina LAR, Pastre CM, Padovani CR, Vanderlei LCM. Influência do perfil clínico e sociodemográfico na qualidade de vida de cardiopatas submetidos à reabilitação cardíaca. Conscientiae Saúde. 2011;11(1):59-68.

13. Muela HCS, Bassan R, Serra SM. Avaliação dos benefícios funcionais de um programa de reabilitação cardíaca. Rev Bras Cardiol [internet]. 2011 Jul-Ago [acesso em 2012 Set 20];24(4):241-50.

Disponível

em: http://sociedades.cardiol.br/socerj/revista/2011_04/a_2011_v24_n04_avaliacao.pdf.

14. Instituto Brasileiro de Geografia e Estatística. Pesquisa Nacional por Amostra de Domicílios (PNAD): Sinopse do Censo Demográfico 2010 [internet]. Rio de Janeiro: IBGE; 2011 [acesso em 2012 Ago 19]. Disponível em: http://www.ibge.gov.br/home.

15. Fernandes MVB, Aliti G, Souza EN. Perfil de pacientes submetidos à cirurgia de revascularização miocárdica: implicações para o cuidado de enfermagem. Rev Eletrônica Enferm [internet]. 2009 [acesso em 2012 Set 20];11(4):993-9. Disponível em: http: //www.fen.ufg.br/revista/v11/n4/pdf/v11n4a25.pdf.

16. Ribeiro MCSA, Barata RB, Almeida MF, Silva ZPS. Perfil sociodemográfico e padrão de utilização de serviços de saúde para usuários e não usuários do SUS: PNAD 2003. Ciênc Saúde Coletiva [internet]. 2006 Dez [acesso em 2012 Set 19];11(4):1011-22. Disponível em: http://www.scielo.br/pdf/csc/v11n4/32337.pdf.

17. Moraes TPR, Dantas RAS. Avaliação do suporte social entre pacientes cardíacos cirúrgicos: subsídio para o planejamento da assistência de enfermagem. Rev Latino-Am Enferm [internet]. 2007 Mar-Abr [acesso em 2012 Out 19];15(2):323-9. Disponível em: http://www.scielo.br/pdf/rlae/v15n2/pt_v15n2a20.pdf.

18. Secretaria de Políticas de Saúde. Programa Saúde da Família. Rev Saúde Pública. 2000;34:316-9. 
19. Martins LN, Souza LS, Silva CF, Machado RS, Silva CEF, Vilagra MM, et al. Prevalência dos fatores de risco cardiovascular em adultos admitidos na unidade de dor torácica em vassouras, RJ. Rev Bras Cardiol [internet]. 2011 Set-Out [acesso em 2012 Set 19];24(5):299307.

em: http://sociedades.cardiol.br/socerj/revista/2011_05/2a_2011_v24_n05_04prevalencia.pdf. 20. Santana VTS, Squassoni SD, Neder JA, Fiss E. Influência do tabagismo atual na aderência e nas respostas à reabilitação pulmonar em pacientes com DPOC. Rev Bras Fisioter. 2010 Jan-Fev;14(1):16-23.

21. Aquino RD, Fonseca SM, Lourenço EPL, Leite AL, Bettencourt ARC. Mapeamento dos diagnósticos de enfermagem em uma unidade de pneumologia. Acta Paul Enferm. 2011;24(2):192-8.

22. Simonetti JP, Batista L, Carvalho LR. Hábitos de saúde e fatores de risco em pacientes hipertensos. Rev Latino-Am Enferm [internet]. 2002 Maio-Jun [acesso em 2012 Ago 20];10(3):415-22. Disponível em: http://www.scielo.br/pdf/rlae/v10n3/13351.pdf.

23. Andrade LT, Araújo EG, Andrade KRP, Soares DM, Ciancal TCM. Papel da enfermagem na reabilitação física. Rev Bras Enferm [internet]. 2010 Nov-Dez [acesso em 2012 Out 19];63(6):1056-60. Disponível em: http://www.scielo.br/pdf/reben/v63n6/29.pdf.

24. Gardenghi G, Dias FD. Reabilitação cardiovascular em pacientes cardiopatas. Integração. 2007;51:387-92.

25. Eyken EBBDOV, Moraes CL. Prevalência de fatores de risco para doenças cardiovasculares entre homens de uma população urbana do Sudeste do Brasil. Cad Saúde Pública [internet]. 2009 Jan [acesso em 2012 Ago 18];25(1):111-23. Disponível em: http: //www.scielo.br/pdf/csp/v25n1/12.pdf.

26. Carvalho CQ, Alfenas RCG. Índice glicêmico: uma abordagem crítica acerca de sua utilização na prevenção e no tratamento de fatores de risco cardiovasculares. Rev Nutr. 2008 Set-Out [acesso em 2012 Set 19];21(5):577-87. Disponível em: http://www.scielo.br/pdf/rn/v21n5/a10v21n5.pdf. 